\title{
The Influence of Parent Attachment on Self-Regulation in Recovery Among Registered Drug Addicts
}

\author{
Wan Maisarah Wan Abu Mansor, Nor Aniza Ahmad, Siti Aishah Hassan \\ Faculty of Educational Studies, Universiti Putra Malaysia, Serdang, Malaysia \\ Corresponding e-mail: nor_aniza@upm.edu.my
}

\begin{abstract}
Drug addiction is an issue that should be taken seriously by all. The growing number of drug addicts from time to time has led to a variety of prevention, enforcement and rehabilitation approaches use to solve the problem. This research aims to identify the relationship between parent attachment and self-regulation in drug addiction recovery. The research has been using descriptive and correlational study design. Stratified random sampling was used to determine the number of drug addicts that have been selected as a sample to represent each district of the state. The study involved a total of 300 registered drug addicts aged between 19 and 36 years old. The instruments that were used contain of demographic questionnaire, parent attachment questionnaire and self-regulation questionnaire. Descriptive data was analysed by using SPSS 22.0 software. The results showed that there was a significant relationship between Parent Attachment and Self-Regulation $(\mathrm{N}=300, \mathrm{r}=0.390 * *, \mathrm{p}=0.01)$.
\end{abstract}

Keywords: parent attachment, self-regulation, drug addicts

\section{INTRODUCTION}

Even though Malaysia's development is thriving, the issue of drug addiction is a serious issue that has not yet been fully addressed (Che Amat, 2013). The National Anti-Drug Agency (AADK), through its three strategies; Public Prevention and Awareness, Treatment and Rehabilitation, and Enforcement is always working to combat the current drug problems and confining those who have not yet been falling into the harms. AADK also encourages these preventive strategies to be implemented by parents, employers, schools and community groups. However, up to this year, in 2016, the number of drug addicts continues to increase and more efforts have been made to restraint the problem.

AADK provides treatment and rehabilitation programs to registered drug addicts accordance to district supervision, whereby, often runthrough psychosocial programs to increase the
Level of self-regulation in preventing them to relapse. In addition, AADK also implements a Family Association programme of which involves parents and close families to create a healthy family environment in aiding the drug addiction recovery process. Relapsing usually occur during the first year after the completion of treatment sessions (Fernandez-Montalvo, Lopez-Goni, Illescas, Landa, \& Lorea, 2007).

In addressing the problem of relapse, AADK is often emphasized on the relapse prevention elements for registered drug addicts through existing treatment and rehabilitation programs during the monitoring period. This is in ensemble with what has been emphasized by Welsh \& Liberto (2001) that relapse prevention plan is an important element which needs to be highlighted during a recovery period of one who has been involved in drug addiction. 
A concerned parents will make their children tend be less involved in negative influences such as drugs, alcohol, free sex, and vandalism (Bannink, Broeren, Van De Looij-Jansen, \& Raat, 2013). A single mother and father who cooperate in caring of their children is still not compatible with the parents who live together, whereby, children who live with both parents will be having healthy environment and stable emotion (Fagan, T.K. \& Wise, 2007). Therefore, it can be concluded that parents' attachments with deep affection are more likely of producing children with high levels of self-regulation compared with divorced parents.

The total number of registered drug addicts in Malaysia until December 01, 2016 is 61,683, of whom 15,636 are recurring cases. An overview shows that $25 \%$ of the total is a recurring addition.

According to Quinn \& Fromme (2010), high levels of self-regulation will prevent a person from getting involved in unhealthy activities such as taking excessive alcohol, free sex as well as similar activity like drug addiction. This shows that drug addicts may have low regulatory levels if they still unable to resist themselves from getting trapped into it.

In the study of marijuana, Dvorak \& Day (2014) found that, those who are involved in marijuana addiction are the individuals who have difficulty in determining their own level of self-regulation.

Attachment and self-regulation are inextricably intertwined elements (Orehek, VazeouNieuwenhuis, Quick, \& Weaverling, 2017). In the research regarding the importance of parental involvement in the prevention of abusing prohibited substances, Wong (2008) stated that the active involvement of parents in selfdevelopment of their children will save them from taking the prohibited substances.

The purpose of this study was to identify the level of self-regulation of registered drug addicts and to identify the relationship between parental attachment and self-regulation in education of registered drug addicts.

\section{METHODOLOGY}

\subsection{Research Design}

A descriptive correlation design was employed in this study. A descriptive correlation study aims to determine the relationship that exists between two or more variables (dependent or independent). This method is highly capable to assess the present of relationships between the factors that have been studied (Chua Yan Piaw, 2014).

\subsection{Population and Sampling}

The total number of drug addicts registered in one of the states in Malaysia is 4,980. Through stratified random sampling, 300 people have been selected to represent each district of the state. Respondents' ranged in age from 19 - 36 years.

\subsection{Instrument}

The study was using questionnaire as the instrument. The questionnaire was distributed to obtain feedback from respondents to gather data and information that related to the study. The instrument consists of 3 parts; part $\mathrm{A}$ : demographic questionnaire, part B: parent attachment questionnaire that has been translated by Zakaria (2011) and part C: self-regulatory questionnaire by (Brown, Miller, \& Lawendowski, 1999). Part A and Part B have five answer options containing of likert scale questions

\subsubsection{Validity}

The validity of the instrument has been verified by three field experts of local universities.

\subsubsection{Reliability}

Table 1.0

\begin{tabular}{lcc}
\hline \multirow{2}{*}{ Construct } & \multicolumn{2}{c}{ Cronbach's Alpha } \\
\cline { 2 - 3 } & $\begin{array}{c}\text { Pilot } \\
\text { test }\end{array}$ & $\begin{array}{r}\text { Actual } \\
\text { Research }\end{array}$ \\
\hline $\begin{array}{l}\text { Parent } \\
\text { attachment }\end{array}$ & .701 & .717 \\
Self-Regulation & .713 & .848 \\
\hline
\end{tabular}


Based on the value of "Cronbach's Alpha" in Table 1.0, it can be concluded that the reliability value of the instrument obtained from this analysis is within $0.7-0.8$, Which is good. According to Pallant (2011), the instrument is considering good if the value of "Cronbach's Alpha" is 0.7 and above.

\section{FINDINGS}

\subsection{Respondent Profile}

About (98.7\%) of the respondents are men while $(1.3 \%)$ are women. From the aspect of race, (98\%) of males are Malay, (1.0\%) India, $(0.7 \%)$ Chinese and Others are $(0.3 \%)$. Most of respondents $(91.4 \%$,) are between 24 years old to 36 years old, while few are between 19 years to 23 years old. About (49.7\%) of respondents are from divorced parents while $50.3 \%$ of respondents have non-divorced parents. Most of the respondents $(83.3 \%)$, have low income levels. About (75\%) of respondents live in kampong area.

\subsection{Self-Regulation Level}

The researcher categories the score scale of SelfRegulation as the following Table 2.0

Table 2.0 Score Scale of Self-Regulation

\begin{tabular}{ll}
\hline Score & Categories \\
\hline$>239$ & High \\
$214-238$ & Medium \\
$<213$ & Low \\
& \\
\hline
\end{tabular}

Table 3.0 shows the distribution of respondents according to the level of self-regulation based on the categories that have been developed by the researcher.

Table 3.0 The distribution of respondents according to the level of self-regulation

\begin{tabular}{llc}
\hline Level & Total & $\begin{array}{c}\text { Percent } \\
(\mathbf{\%})\end{array}$ \\
\hline Low & 116 & 38.7 \\
Medium & 141 & 47.0 \\
High & 43 & 14.3 \\
\hline Total & $\mathbf{3 0 0}$ & $\mathbf{1 0 0}$ \\
\hline
\end{tabular}

Table 3.0 shows that the Self-Regulation for the majority of the respondents, 141 people (47\%) is at medium-level, meanwhile $116 \quad(38.7 \%)$ at low-level and $43(14.3 \%)$ at high-level of SelfRegulation.

Table 4.0 Total mean for the construct of Self-Regulation

\begin{tabular}{ccc}
\hline Mean & $\begin{array}{c}\text { Standard } \\
\text { Deviation }\end{array}$ & $\mathbf{N}$ \\
\hline 219.481 & 21.290 & 300 \\
\hline
\end{tabular}

The total mean for the construct of SelfRegulation is 219.481 with the standard deviation of 21.290. This shows that mean of the value fall over the score of $214-238$ which is at medium level. Based on the finding, it can be concluded that the Self-Regulation of Registered Drug Addicts is at the medium level

\subsection{Relationship between parent attachments with Self-Regulation}

Table 5.0 shows the relationship between Parent Attachment with Self-Regulation

Table 5.0 Relationship between Parent Attachments with Self-Regulation

\begin{tabular}{|c|c|c|}
\hline $\begin{array}{l}\text { Variabl } \\
\text { e }\end{array}$ & $\begin{array}{c}\text { Self- } \\
\text { Regulatio } \\
\mathbf{n} \\
\text { mean } \\
\mathbf{r} \\
\end{array}$ & $\begin{array}{c}\text { Relationshi } \\
\mathbf{p} \\
\text { interpretation } \\
\mathbf{p}\end{array}$ \\
\hline $\begin{array}{c}\text { Parent } \\
\text { attachment }\end{array}$ & $0.390^{* *}$ & $\begin{array}{l}\text { Low positive } \\
\text { relationship }\end{array}$ \\
\hline
\end{tabular}

Pearson Correlation Test has shown a positive significant correlation between parent attachment with the mean of Self-Regulation ( $\mathrm{N}$ $=300, \mathrm{r}=0.390 * *, \mathrm{p}=0.01$ ).

\section{DISCUSSION}

From the findings, it can be conclude that this research supports the findings of Quinn \& Fromme (2010). Registered drug addicts are the individuals who have been ordered by the court to undergo treatment and rehabilitation at 
AADK. Only few registered drug addicts seek treatment and rehabilitation voluntary. Therefore, it is the biggest challenge to form a self-regulation of these groups to not relapse. However, the number of addicts' relapse per year increasing to $25 \%$ of the total number of registered drug addicts. This shows that the selfregulation of the registered drug addicts is still weak.

The significant relationship between parent attachment and self-regulation of the registered drug addicts also comparable with the findings of Orehek et al (2017) and (Wong, 2008) who argue that attachment and self-regulation are intertwined

From the findings of this study, AADK can improve the treatment and rehabilitation programs for all registered drug addicts as well as for CCRC residents (Cure \& Care Rehabilitation Center). It is to prepare them to cope with any trigger when be there in the community setting.

Besides that, the research findings also may benefit parents, schools, employers in the workplace as well as local leaders in preventing the new addicts. These groups are the stakeholders who involved in self-regulation development of individuals who are at risk of drug addiction especially the adolescent.

\section{CONCLUSION}

Parents as the key stakeholders are essential to make sure their children are free from drug addiction. Good parents' attachment will produce high levels of self-regulation inside the children, whereby, it can be a strong defense to avoid drug addiction. It is recommended that such studies be extended to whole Malaysia including Sabah and Sarawak. Future studies are suggested to examine in-depth the Parent Appraisal and Emotional Self-Regulation among drug addicts.

\section{REFERENCES}

Bannink, R., Broeren, S., Van De Looij-Jansen, P. M., \& Raat, H. (2013). Associations between parent-adolescent attachment relationship quality, negative life events and mental health. PLoS ONE, 8(11). https://doi.org/10.1371/journal.pone.0080 812

Brown, J. M., Miller, W. R., \& Lawendowski, L. a. (1999). The Self-Regulation Questionnaire (SRQ). Innovations in Clinical Practice: A Source Book (Vol. 17), 281-289. https://doi.org/10.1080/08870446.2014.91 5969

Che Amat, M. A. (2013). Meneroka Faktor Relaps dan Pandangan Terhadap Perkhidmatan dalam Kalangan Penghuni Pusat Pemulihan Dadah di Kelantan. UPM.

Chua Yan Piaw. (2014). Kaedah Dan Statistik Penyelidikan Buku 5: Ujian Regresi, Analisis Faktor dan Analisis SEM. Mc Graw Hill Education. https://doi.org/10.1016/S09694765(04)00066-9

Dvorak, R. D., \& Day, A. M. (2014). Marijuana and self-regulation: Examining likelihood and intensity of use and problems. Addictive Behaviors, 39(3), 709-712. https://doi.org/10.1016/j.addbeh.2013.11.0 01

Fagan, T.K. \& Wise, P. a. (2007). Roles and Functions of School Psychologists. School Psychology: Past, Present, and Furture, 105-156. https://doi.org/10.5926/arepj1962.40.0_17 7

Fernandez-Montalvo, J., Lopez-Goni, J. J., Illescas, C., Landa, N., \& Lorea, I. (2007). Relapse precipitants in addictions: Results in a therapeutic community. JOURNAL OF ADDICTIVE DISEASES, 26(4), 55-61. https://doi.org/10.1300/J069v26n04_07

Orehek, E., Vazeou-Nieuwenhuis, A., Quick, E., \& Weaverling, G. C. (2017). Attachment 
and Self-Regulation. Personality and Social Psychology Bulletin, 43(3), 365380.

https://doi.org/10.1177/014616721668529 2

Pallant, J. (2011). A step by step guide to data analysis using SPSS. Alen \& Unwin, 359. https://doi.org/10.1046/j.1365-

2648.2001.2027c.x

Quinn, P. D., \& Fromme, K. (2010). Selfregulation as a protective factor against risky drinking and sexual behavior. Psychology of Addictive Behaviors: Journal of the Society of Psychologists in Addictive Behaviors, 24(3), 376-385. https://doi.org/10.1037/a0018547

Welsh, C. J., \& Liberto, J. (2001). The use of medication for relapse prevention in substance dependence disorders. Journal of Psychiatric Practice, 7(1), 15-31. https://doi.org/http://dx.doi.org/10.1097/0 0131746-200101000-00003

Wong, M. M. (2008). Perceptions of Parental Involvement and Autonomy Support: Their Relations with Self-Regulation, Academic Performance, Substance Use and Resilience among Adolescents. North American Journal of Psychology, 10(3), 497-518.

Zakaria, N. (2011). Pengaruh Faktor Kecerdasan Emosi dan Spiritual serta Faktor Sosial Terhadap Strategi Kognitif Regulasi Kendiri Emosi dan Tingkah Laku Sosial Remaja. UPM. 